\title{
МЕТОДЫ ИССЛЕДОВАНИЯ ТЕЧЕНИЯ БЕРЕМЕННОСТИ У ЖЕНЩИН С СИНДРОМОМ НЕДИФФЕРЕНЦИРОВАННОЙ ДИСПЛАЗИИ СОЕДИНИТЕЛЬНОЙ ТКАНИ
}

\section{METHODS OF INVESTIGATION OF PREGNANCY IN WOMEN WITH UNDIFFERENTIATED CONNECTIVE TISSUE DYSPLASIA SYNDROME}

T. Fadeeva

Summary. The problem of undifferentiated connective tissue dysplasia (NDST) is very relevant, since there is a wide spread of this pathology among women of reproductive age. Early detection of this pathology is necessary to assess the course of pregnancy and the outcome of childbirth for the mother and child. In obstetrics, forecasting is widely used to determine the weakness of childbirth, the need for and outcome of a cesarean section, and to determine the course of pregnancy. In this paper, we studied methods for studying the course of pregnancy in women with undifferentiated connective tissue dysplasia (NDS) syndrome and methods for examining the fetus. For this purpose, a set of clinical methods of examination and observation was used: research of phenotypic signs of NDST, echocardiography, biochemical blood analysis, etc. These methods of studying the course of pregnancy of women suffering from NDST will improve the outcomes of pregnancy and childbirth.

Keywords: NDST syndrome, pregnancy, phenotypic signs of NDST, biochemical blood analysis, fetal research methods.

\section{Актуа^ьность}

B настоящее время прогнозирование протекания тех или иных процессов в организме человека активно применяется в современной медицине и здравоохранении. Оно необходимо для оптимизации мер в здравоохранении по предотвращению нежелательных последствий. В акушерстве прогнозирование широко применяется для определения слабости родов, необходимости и исхода кесарева сечения, определения протекания беременности при пиелонефрите и отрицательном резусе-факторе у беременных [1]. При наличии у беременной недифференцированной дисплазии соединительной ткани (НДСТ) прогнозируются возможные осложнении протекания беременности и родов. Проблема НДСТ является очень актуальной, так как отмечается широкое распространение данной патологии среди женщин репродуктивного возраста, что примерно равно $20-30 \%$ от общего числа женщин.
Фадеева Татьяна Сергеевна

Врач акушер-гинеколог, г. Калуга fdv_tana@mail.ru

Аннотация. Проблема недифференцированной дисплазии соединительной ткани (НДСТ) является очень актуальной, так как отмечается широкое распространение данной патологии среди женщин репродуктивного возраста. Раннее выявление данной патологии необходимо для оценки течения беременности и исхода родов для матери и ребенка. В акушерстве прогнозирование широко применяется для определения слабости родов, необходимости и исхода кесарева сечения, определения протекания беременности. В данной работе были изучены методы исследования течения беременности у женщин с синдромом недифференцированной дисплазии соединительной ткани (НДСТ) и методы исследования плода. Для этого применялась совокупность клинических методов обследования и наблюдения: исследование фенотипических признаков НДСТ, эхокардиография, биохимический анализ крови и т.д. Данные методы исследования течения беременности женщин, страдающих НДСТ, позволят улучшить исходы беременности и родов.

Ключевые слова: синдром НДСТ, беременность, фенотипические признаки НДСТ, биохимический анализ крови, методы исследования плода.

\section{Цель исслеАования}

В литературе практически отсутствует оценка течения беременности и исхода родов в зависимости от степени тяжести НДСТ. Тактика оказания диагностических услуг беременным женщинам, страдающим НДСТ позволит сделать исход родов более благоприятным и улучшит последующий прогноз для матери и новорожденного. В настоящей работе были изучены методы исследования течения беременности у женщин с синдромом НДСТ и методы исследования плода.

\section{Материалы и метолы \\ исслеАования}

Объектом данного исследования являлись 900 беременных женщин, наблюдение которых происходило в период беременности и в течении 4х дней после родов. Также было проведено исследование их новоро- 
жденных детей. Все пациентки подписали добровольное информированное согласие на их участие в проведенном исследовании.

Все исследование базировалось на изучении общего и акушерско-гинекологического анамнеза, специфики течения беременности, родов и послеродового периода женщин с НДСТ. Для этого применялась совокупность клинических методов обследования и наблюдения. Проводилось динамическое исследование температуры, пульса, артериального давления, веса и общего состояния. Кроме того, огромное внимание уделялось исследованиям периферической крови (на белок, функциональные пробы печени), мочи (пробы Зимницкого, Нечипоренко, микроскопия мочевого осадка). Во время проведения исследования также проходили консультации терапевта, окулиста, в редких случаях невропатолога, уролога и эндокринолога.

\section{Результаты исслеАования}

\section{Методы исследования беременных женщин}

\section{Исследование фенотипических признаков НДСТ}

При исследовании внешних фенотипических признаков НДСТ руководствовались фенотипической картой М. Дж. Глесби [2], которая была модифицирована Мартыновым А.И. в 1996 [3]. Данная карта включает в себя следующие фенотипические признаки:

- Долихостеномелия - для нахождения которой используется индекс соотношения рук и роста, который должен быть более 7,6 см.

- Наличие воронкообразной грудной клетки 1-2 степени. Она чаще проявляется у мужчин, чем у женщин. Характеризуется наличием углубления по средней линии грудины (на 0,3-0,5 cм и 0,5-0,7 см), наличием килевидной грудной клетки с килевидным выпячиванием грудины и крыловидными лопатками. Края лопаток выпирают от общей линии спины настолько, что становится возможным просунуть кончики пальцев под них.

- Арахнодактилия - наличие длинной и узкой ладони и длинных пальцев. Для ее определения проводится тест большого пальца (при наличии арахнодактилии дистальные фаланги большого пальца смещены за ульнарный край ладони) и тест запястья (дистальные фаланги первого и пятого пальцев должны частично перекрещиваться при обхвате запястья противоположной руки).

- Патологии позвоночника, которые определяются при клиническом обследовании. К ним относятся сколиоз и гиперлордоз поясничного отдела, который проявляется в искривлении позвоночника вперед с превышением допустимой физиологической нормы.

- Все аномалии зрения, такие как миопия, астигматизм, дистопия и т.д., определялись посредством осмотра окулистом и проведения соответствующего опроса.

- Информацию о всех варикозных расширениях вен исследовали посредствам осмотра пациенток и использовании результатов флеграфии.

Все аномалии массы тела определяются благодаря индексу Кетле [4], который находится по формуле:

$$
I=\frac{m}{h^{2}}
$$

где:

$m$ - масса тела в килограммах,

$h$ - рост в метрах,

и измеряется в кг/м².

Чтобы проверить, присутствует ли у женщины дефицит массы тела, необходимо рассчитать индекс Варги [5], который находится по формуле:

$$
\text { ИВ }=\frac{\text { масса тела }(\mathrm{\kappa r})}{\operatorname{pocт}(\mathrm{M})}-\frac{\text { возраст }}{100} ;
$$

Если индекс (ИВ) равен 1,7-1,5, то уменьшение массы тела является умеренным, если менее 1,5, то повышенное снижение.

Гипермобильность суставов является характерным признаком НДСТ как у детей, так и у взрослых. Однако, частота наличия данного признака повышается в зависимости от проявления других признаков ДСТ, но является различной в разных популяциях. В меньшей степени она прослеживается у европейцев, в большей степени - у индейцев. Наибольшая подвижность суставов проявляется у детей в возрасте 13-14 лет; к 2530 годам она снижается в 3-5 раз. Однако, гипермобильность суставов характерна именно для подросткового возраста, в данный период наблюдается самое большое количество эластина, вследствие чего происходит увеличение удельного веса эластических волокон [6]. Гипермобильность суставов может снижаться со временем. Если у человека присутствует гипермобильный синдром во второй половине жизни, то он стимулирует развитие разнообразных поражений околосуставных мягких тканей, что в свою очередь объясняется тем, что на уже имеющийся дефект соединительной ткани (СТ) более легко накладываются инволютивные процессы в сухожильно-связочном аппарате [7]. Для выявления гипермобильности суставов проводится тщательное обследование и прохождение тестов таких, как пассивное приведение большого пальца через 
Таблица 1. Критерии синдрома гипермобильности суставов

\begin{tabular}{|c|c|}
\hline Большие критерии & Малые критерии \\
\hline Счет по шкале Бейтона (4 или более баллов) & Счет по шкале Бейтона (1-3 баллов) \\
\hline \multirow[t]{7}{*}{$\begin{array}{l}\text { Артралгия должна проявляться более } 3 \text { месяцев в четырех или } \\
\text { более суставах }\end{array}$} & $\begin{array}{l}\text { Артралгия должна проявляться в одном-трех суставах, может } \\
\text { встречаться люмбалгия, спондилез, спондилолиз, спондилолистез }\end{array}$ \\
\hline & Вывих или подвывих в одном или нескольких суставах. \\
\hline & Периартикулярные поражения более 2 локализаций. \\
\hline & Наличие высокого роста, худощавости, арахнодактилии. \\
\hline & $\begin{array}{l}\text { Проявление аномальности кожи: тонкость, гиперрастяжимость, } \\
\text { стрии, атрофические рубцы. Для проверки растяжимости кожи } \\
\text { необходимо тестировать тыльную сторону кисти, кончик носа и лоб. }\end{array}$ \\
\hline & Наличие нависающих век, миопии, антимонголодной складки. \\
\hline & $\begin{array}{l}\text { Наличие варикозных вен, грыжи, опущения матки, прямой кишки. } \\
\text { Варикозное расширение вен малого таза часто проявляется } \\
\text { в молодом возрасте, но с возрастом прогрессирует. Например, } \\
\text { данная патология у девочек в возрасте 3-17 лет встречается } \\
\text { в 19,4\%, у женщин репродуктивного возраста отмечается } \\
\text { ее наличие уже в 80\% случаев [10]. Данное заболевание } \\
\text { часто проявляется у девочек в пубертатном возрасте вместе } \\
\text { с врожденной слабостью СТ, что связано с влиянием гормонов } \\
\text { (эстрогенов) на развитие СТ. }\end{array}$ \\
\hline
\end{tabular}

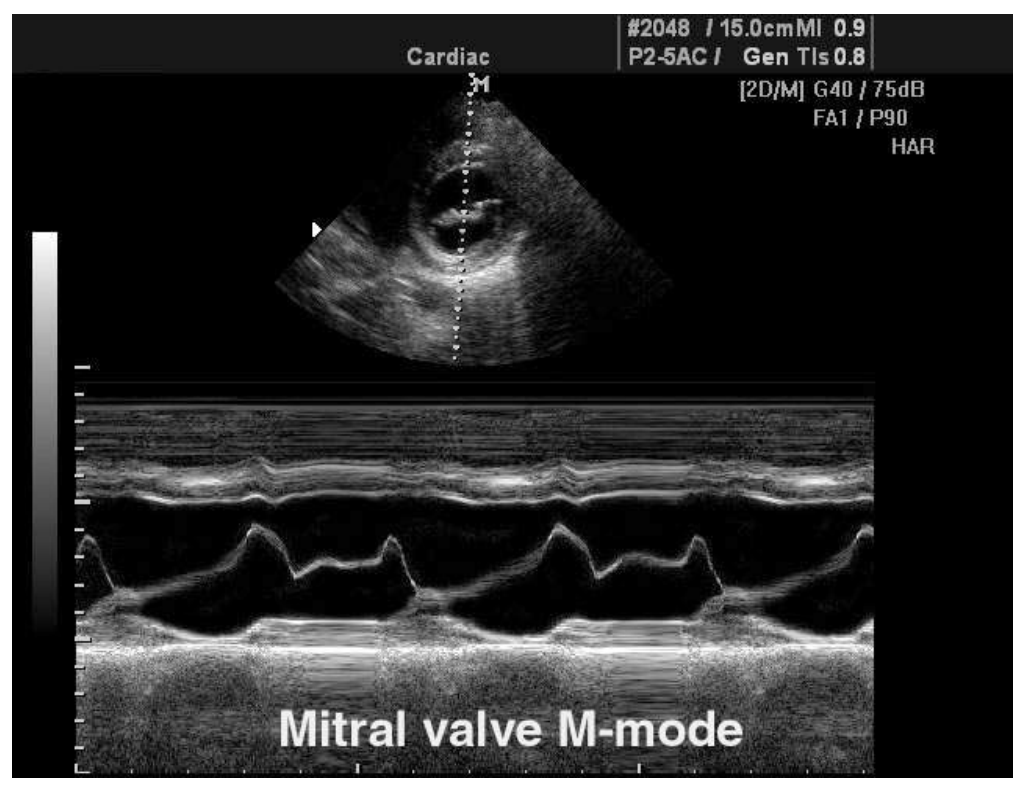

Рис. 1. Графического изображения вибраций стенок сердца и створок клапана в дихотомическом режиме (М-режим).

сторону до соприкосновения с предплечьем, переразгибание в суставах пальцев, переразгибание мизинца до 90 градусов и т.д [8]. Необходимо отметить, что гипермобильность 1-го плюснефалангового сустава может привести к развитию одного из основных клинических признаков поперечного плоскостопия [9]. Все критерии синдрома гипермобильности суставов подразделяются на большие и малые, которые представлены в Таблице 1.
Для того чтобы поставить диагноз НДСТ с гипермобильностью суставов необходимо наличие сочетания двух больших/одного большого и двух малых /четырех малых критериев.

\section{ЭхокарАиография}

При определении НДСТ посредствам эхокардиографии существенными являются следующие режимы: 


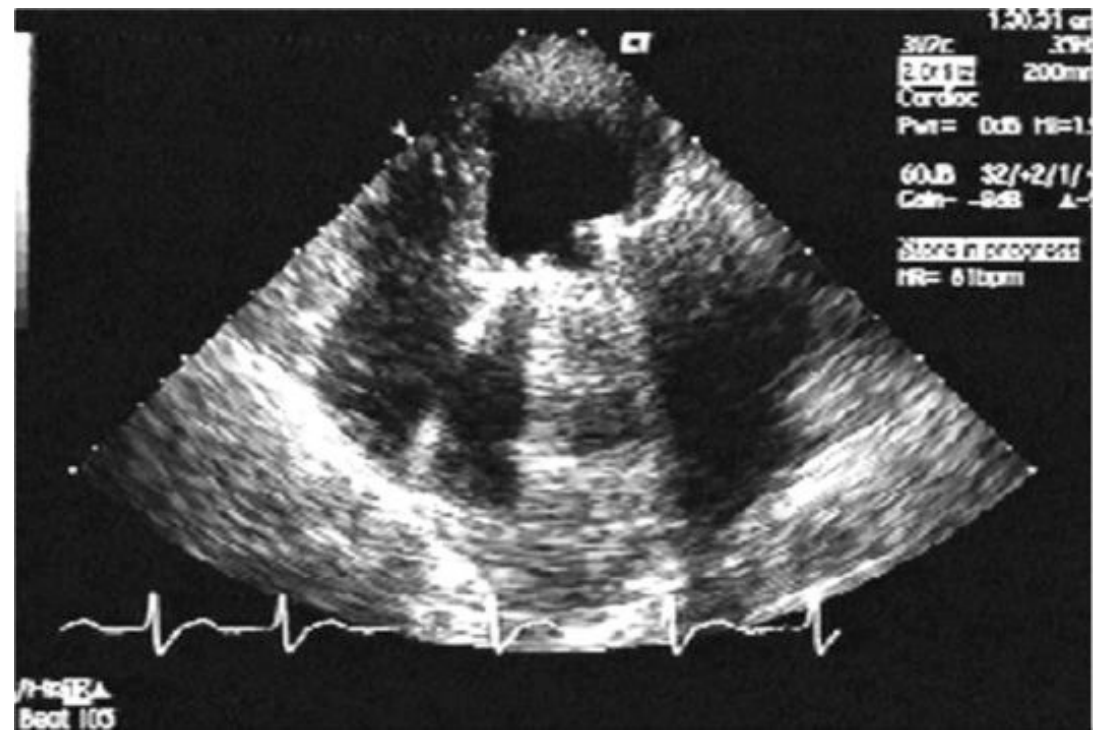

Рис. 2. Эхокардиография (В-режим). Апикальная четырехкамерная позиция, нормально функционирующий механический двустворчатый протез митрального клапана, атриомегалия, акустическая тень от протеза в левом предсердии.

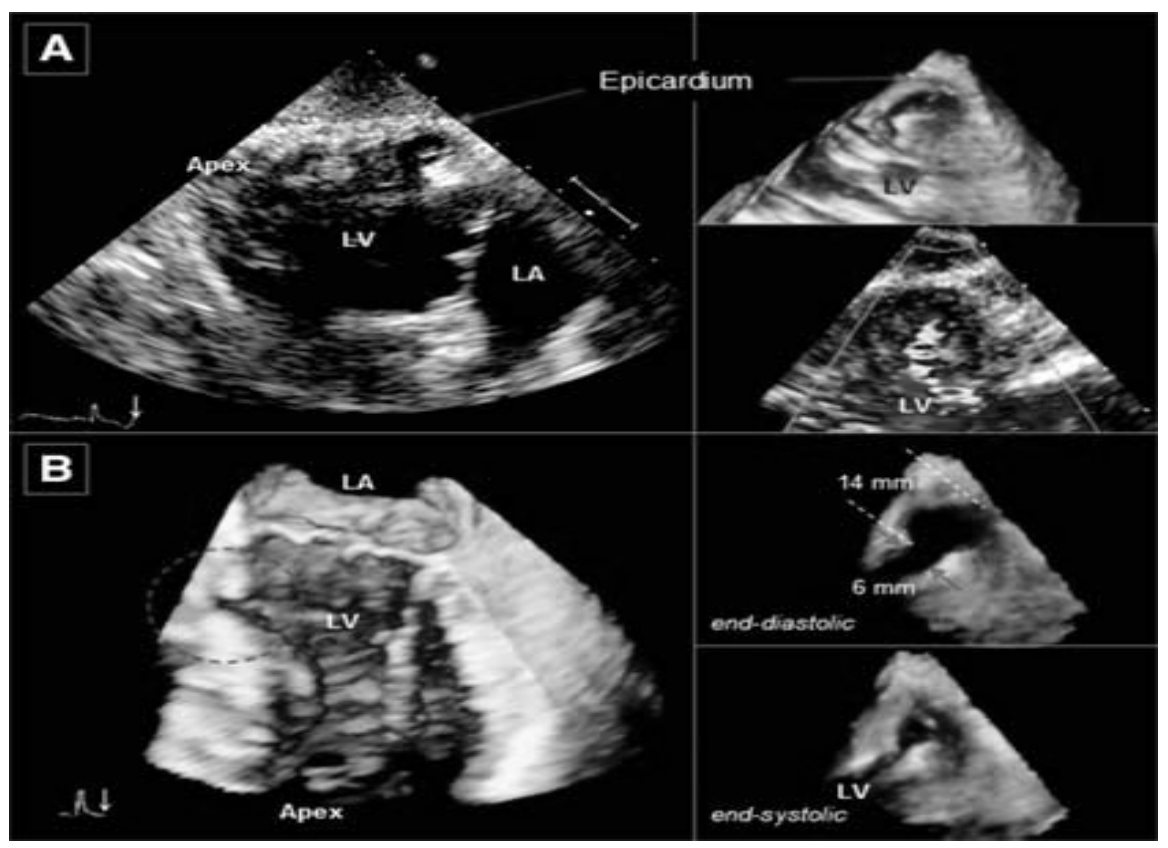

Рис. 3. Допплер эхокардиография

- М-режим, он предназначен для предоставления графического изображения вибраций стенок сердца и створок клапана в дихотомическом режиме. Данный режим необходим при оценке размеров сердца и систолической функции желудочков в реальном времени (Рисунок 1.).

- В-режим представляет из себя двухмерную эхокардиографию. Позволяет получить изобра- жение сердца по длинной и короткой оси в реальном времени. Он необходим при оценке размеров полостей сердца, толщины стенок желудочков, состояние клапанного аппарата, глобальную и локальную сократимость желудочков, наличие тромбоза полостей и т.п. (Рисунок 2.).

- Допплер эхокардиография, которая может быть импульсной, цветной, нервно-волновой. Этот 
способ необходим для исследований направления кровотока, измерении его скоростных характеристик и т.д. (Рисунок 3).

\section{Биохимический анализ крови}

Показателями любой дисплазии соединительной ткани служит дефицит магния в организме женщины и показатель уровня оксипролина.

Рассмотрим, как происходит анализ оксипролина в периферической крови. Для этого в 3 центрифужные пробирки выливают по 1 мл исследуемой сыворотки или плазмы крови, 0,05 мл хлорной кислоты и 0,5 мл трихлоруксусной кислоты. Содержимое смешивается, нагревается до $75-80^{\circ} \mathrm{C}$ на кипящей водяной бане, охлаждается до $18-22{ }^{\circ} \mathrm{C}$ и помещается в центрифугу на 5-6 минут. Количество оборотов должно быть равно 3000 об/мин.

Остаточные компоненты сыворотки крови и плазмы в определенном количестве помещают в мерные центрифужные пробирки. 1-ю пробирку с содержимым необходимо поставить в воду со льдом или нейтрализовать содержимое, а 2-ю и 3-ю пробирки закрывают пылеуловителями (часовое стекло), ставят на кипящую водяную баню на 40 мин и охлаждают до $18-22^{\circ} \mathrm{C}$.

Содержимое пробирок, после добавления к ним по одной капле раствора фенолфталеина, нейтрализовали раствором едкого калия (6 мл). Необходимо добиться появления устойчивой слабо пурпурной окраски по всему объему жидкости. Если появляется интенсивная окраска, в смесь добавляют каплю хлористой кислоты (происходит процесс нейтрализации щелочью). Объем жидкости во всех пробирках вырос до 3,8-4 мл.

К 3 пробирке (первые две являются опытными пробирками, третья контрольной, в ней отсутствует НДСТ) при смешении компонентов добавляют по 0,5 мл раствора хлорамина. В опытные пробирки добавляется 0,5 мл хлорной кислоты и 0,5 мл реактива № 6, а в контрольную пробирку добавляют 0,1 мл хлорной кислоты и 0,5 мл этанола. Все смешивают, нагревают до $75-80^{\circ} \mathrm{C}$ на водяной бане, затем охлаждают до $18-22^{\circ} \mathrm{C}$ и добавляют по 4 мл реактива № 8. Содержимое всех пробирок встряхивают, загружают в центрифугу на 10 мин, при этом необходимы следующие параметры: 3000 об/мин, супернатант необходимо фотометрировать при длине волны 560 нм, в кюветах с длиной оптического пути 2 см.

Содержимое первой пробирки фотометрируют против реактива № 8, второй пробирки - против контроля, в них наблюдается отсутствие хромогена, который характерен для оксипролина. Содержимое свободного (пробирка 1) и суммарного (пробирка 2) оксипролина рассчитывают по калибровочной кривой и выражают в микромолях на 1 л сыворотки крови. В случае наличия дефицита сыворотки крови, можно анализировать лишь один из данных показателей. По разности содержания свободного и суммарного оксипролина находили количество связанного оксипролина.

При биохимическом анализе уровня магния в периферической крови используют компьютерные программы и реактивы. Примерами такой программы является «Коне Ультра».

\section{Метолы \\ исслеАОвания п^оАа}

На данный момент наиболее часто применяются методы, связанные с определением и контролем сывороточных белков.

- Альфа-фетопротеин (АФП) - специфический фетальный альфа-глобулин. Необходим для транспортировки гормонов, аминокислот, микроэлементов к различным клеткам и тканям организма. Его возможно уже определить на 1114-й неделе беременности (максимально в крови плода может присутствовать 10\% данного белка). Анализ АФП применяется для определения срока беременности и зрелости плода, а также при прогнозировании синдрома дыхательной недостаточности при рождении.

- Хорионический гонадотропин человека (хориогонадотропин, ХГЧ) -гликопротеин с молекулярной массой около 46000 D. Он состоит из двух нековалентно связанных субъединиц - альфа и бета. Только бета-субъединица иммунологически специфична для ХГЧ, поэтому специфическая антисыворотка у подавляющего большинства диагностических тест-систем направлена именно против бета-цепи. Именно ХГЧ может помочь установить беременность на очень раннем сроке.'

- Децелеращии представляют собой преходящие эпизоды урежения частоты сердечных сокращений (ЧСС) плода на 15 ударов/мин и более продолжительностью 10 сек и более. Савельева с соавторы приводят критерии, которые характерны для нормальной КТГ [11]:

- базальный ритм в диапазоне 120-160 уд/мин;

- амплитуда осцилляций 5-25 уд/мин;

- децелерации отсутствуют;

- акцелерации 2 и более за 10 мин.

С целью унификации оценки данных антенатальной КТГ предложена балльная система [12]: 
- 8-10 баллов - удовлетворительное состояние плода,

- 5-7 баллов - начальные признаки нарушения жизнедеятельности плода,

$\checkmark \quad 4$ балла и менее - серьезные изменения состояния плода.

- Амниоскопия - эндоскопический метод, позволяющий на основании ряда визуальных признаков оценить состояние плода.

\section{Ультразвуковая \\ $\triangle$ ИагНОСТИКа}

Ультразвуковая диагностика является основным методом исследования плода на всей протяженности беременности. Основным принципом при проведении ультразвукового исследования является принцип ALARA (As Low As Reasonably Achievable), что означает: «Столь мало, сколь разумно достижимо в разумных пределах».

С 3-й недели в полости матки можно уже обнаружить начало визуализации плодного яйца в виде эхонегативного образования округлой или овоид-ной формы диаметром 5-6 мм. В 4-5 недель - появляется эмбрион размером 6-7 мм. Головка эмбриона полностью визуализируется с 8-9-й недели и имеет вид отдельного анатомического образования округлой формы средним диаметром 10-11 мм. Оценка жизнедеятельности эмбриона в ранние сроки беременности основывается на регистрации его сердечной деятельности и двигательной активности.

При УзИ регистрировать сердечную деятельность эмбриона можно с 4-5-й недели. Двигательная активность эмбриона выявляется с 7-8-й недели. При изучении развития плода во II и III триместрах беременности измеряют следующие размеры: бипариетальный раз- мер, окружность головки, средние диаметры грудной клетки и живота, длину бедренной кости. Ультразвуковое исследование позволяет проводить оценку деятельности различных органов и систем плода, а также диагностировать врожденные пороки его развития. Для их детальной оценки может использоваться трехмерная эхография, позволяющая получить объемное изображение. При трансвагинальном исследовании четкое изображение хориона можно получить на 5-6-й неделе. Одним из показателей состояния плаценты является ее толщина. К 36-37-й неделе рост плаценты прекращается. В дальнейшем при физиологическом течении беременности ее толщина уменьшается или остается на том же уровне, составляя 3,3-3,6 см.

К инвазивным методам получения плодного материала относятся хорионбиопсия, плацентобиопсия и амниоцентез. В отдельных случаях исследуют непосредственно клетки плода, что достигается с помощью кордоцентеза. Данные методы используются для получения материала для цитогенетических, молекулярных, цитохимических, биохимических и других исследований.

\section{Выво $\triangle \mathrm{b}$}

В данной работе предложен оптимальный метод исследования периода гестации для беременных, страдающих НДСТ, который позволит улучшить исход беременности и родов. После детального применения определенной совокупности методов исследования протекания беременности и состояния плода, можно приступить к прогнозированию течения родов. В ходе данного прогнозирования учитывается множество факторов, оно составляется при помощи компьютерных программ. Можно спрогнозировать: возможные осложнения родов, оценку новорожденных по шкале Апгар, продолжительность родов, продолжительность безводного промежутка и т.д.

\section{ЛИТЕРАТУРА}

1. Анастасьева В.Г., Трунченко Н. В. Особенности течения беременности и исхода родов у беременных с пролапсом митрального клапана // Асtа Вiomedica Scientifica. 2007. № 55 C.18-21.

2. Glesby M.J., Pyentz R. E. Association of mitral valve prolapse and systemic abnormalities of connective tissue // A phenotypic continuum. 1989. V. 262. P. 523-528.

3. Мартынов А.И., Степура 0. В., Остроумова О.Д. Маркеры дисплазии соединительной ткани у больных с идиопатическим пролабированием атриовентрикулярных клапанов и с аномально расположенными хордами // Терапевт арх. 1996. Т. 68. № 2. С. 40-43.

4. Eknoyan G. Adolphe Quetelet (1796-1874)-the average man and indices of obesity // Nephrol. Dial Transplant. 2008. V. 23. No.1. P. 47-51.

5. Васильев 0.С., Левушкин С. П. Сравнительный анализ антропометрических параметров как фенотипических маркеров синдрома дисплазии соединительной ткани у спортсменов // Медицина экстремальных ситуаций. 2015. Т. 1. С. 275-279.

6. Нестеренко 3. В. Дисплазия соединительной ткани - медико-социальный феномен XXI века // Боль. Суставы. Позвоночник. 2012. Т. 1. № 5. С. 17-23.

7. Нечаева Г.И., Викторова И. А., Калинина И. Ю. Диагностика дисплазии соединительной ткани у лиц среднего и пожилого возраста в практике семейного врача // Рос. сем. Врач. 2004. Т. 2. № 8. С. 47-54.

8. Викторова И.А., Коншу Н. В., Румянцев А. В. Синдром гипермобильности суставов: клиническое значение, прогноз, взаимосвязь с риском возникновения остеоартроза // Архивъ внутренней медицины. 2015. Т. 2. № 22. С. 3-6. 
9. Кузьмин В.И., Черкашов А. М., Шарамко Т. Г., Горохов М. А. Наш опыт хирургического лечения больных с поперечным плоскостопием, hallux valgus // Pocсийский медико-биологический вестник имени академика И. П. Павлова. 2016. Т. 24 . № 3.

10. Адамян Л.В., Смольнова Т. Ю. Диагностика и тактика ведения больных с дисплазией соединительной ткани в акушерстве и гинекологии // РМЖ. 2010. Т. 6. C. 41-46.

11. Акушерство: Учебник / Г. М. Савельева, В. И. Кулаков, А44 А. Н. Стрижаков и др.; Под ред. Г. М. Савельевой.- М.: Медицина, 2000. - 816 с.

12. Fischer W.M., Stude I., Brandt H. A suggestion for evaluation of the antepartalcardiotocogram // Zeitschrift. Geburt. Perinatol. 1976. V. 180. P. 117-123.

( Фадеева Татьяна Сергеевна ( fdv_tana@mail.ru).

Журнал «Современная наука: актуальные проблемы теории и практики» 